\title{
E. W. GUDGER
}

State Normal College, Greensboro, N. C.

THE following observations were made while working at the Station of the Bureau of Fisheries at Beaufort, N. C., from May 26 to July 6, 1909, and are recorded in brief in the card catalogue of fishes in the laboratory. While they are but membrana disjecta, they are published in the hope that they may not be devoid of value to those interested in fishes.

These fishes, with the exception of the ones specifically noted from other localities, were taken at the Narrows of Newport River. This is a small stream, whose sunken lower valley is an estuary opening into and forming a part of Beaufort Harbor. The Narrows, distant some seven miles in a northeasterly direction from the laboratory, are at the head of the estuary. Here are a number of "rocks" or reefs built by oysters out on the mudflats. Their names, as one comes to them in going up stream, are Lawton's, Cross and Rockfish Rocks, and a fourth one not named. These reefs, extending out at nearly right angles from the shore, give the channel a very tortuous course. Above them the mudflats spread out so shallow that the river is not navigable save for small boats and by them only at high water. The waters of the ebb tides, collected off these mudflats and largely confined by the reefs to this narrow channel, surge around these points and have scoured out deep holes. Here are to be found large numbers of various fishes, which go up the river to feed on the mudflats and at low tide drop down into these holes. There is no seining ground at Beaufort, known to the writer, where so many different species of fishes may be taken at a single haul of the seine as at the "Rocks" at the Narrows of Newport River.

It is interesting to note that the water at the Narrows

${ }^{1}$ Published by permission of the Commissioner of Fisheries. 
is markedly brackish, owing to the large amount of fresh water brought down by the river. This, coming from the cypress swamps a few miles away, has a decidedly yellowish tinge, the so-called "juniper water." In density this water ranges from 1.0072 just after one of the tropical downpours to which Beaufort is subject, to 1.0184 when only the normal amount of fresh water is brought down. Ten observations for last summer, which was a normal one from the standpoint of rainfall, give an average density of 1.0153 . The average temperature of the water at the time of these observations was $23.6^{\circ} \mathrm{C}$. at a depth of three to five feet.

From May 26 to June 12 we constantly caught large numbers of small menhaden, Brevoortia tyramus, averaging about four inches in length. These are probably young of the previous fall spawning. The average size of adult menhaden is about 12 inches. The largest ever taken at Beaufort by the writer was 15 inches long. The record fish for the Atlantic coast is 18 inches in length.

The writer has taken hundreds of gaff topsail catfish at the Narrows, some quite large, but the record was broken on May 27 by the capture of a female, whose length from tip of nose to tip of caudal fin was $2 \frac{1}{2}$ inches, and whose girth back of the dorsal was 13 inches. The abdomen was distended balloon fashion by the enormous ovary which occupied almost all of its interior, crowding and displacing the stomach and intestine as it enlarged. This ovisac, after being three days in 10-per-cent. formalin, measured $7 \frac{1}{2}$ inches in length and $9 \frac{3}{9}$ inches in girth, and weighed 435 grams.

On May 27, at Cross Rock, we took a large tripletail or flasher, Lobotes surinamensis. Its length all over was

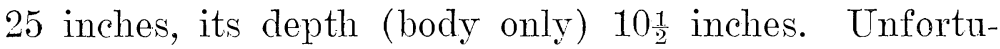
nately there was at hand no means for weighing it. Other large fish of this kind recorded in the card catalogue at the laboratory are, one 21 inches long and $8 \frac{1}{2}$ inches deep, another $18 \frac{1}{2}$ inches long, a third 18 inches long. All were taken by the writer; the last in the pound net two miles up Newport River, the others at the Nar- 
rows. Smith in his "Fishes of North Carolina", notes three large specimens from Beaufort: one of 25 inches, another of 23 inches, and a third (length not given) which weighed 11 pounds.

On May 31, a $14 \frac{1}{8}$ inch specimen of the cutlass-fish, Trichiurus lepturus, was taken at Rockfish Rock. On June 5, another specimen, $15 \frac{3}{4}$ inches long over all, was taken at the same place. These young fish showed clearly the oral breathing valve, which is perhaps more plainly seen in the mouth of the adult than in any other fish known to the writer. One of these fish had had a bite taken out of its dorsal fin and region just over the hinder edge of the pectorals. This has failed to regenerate and the wound had healed, leaving a crescent cut out of the fin.

Not only are these the smallest specimens of this fish ever taken at Beaufort, but they are further interesting because of the fact that both so amply justify the name "hair-tail," since in each the tail is prolonged backward in a long delicate whiplash-like organ, much slenderer in proportion to the size of the body than is the case in the adult. They were probably two, quite certainly not more than three years old. The writer has obtained eggs by "stripping" this fish in August, and sperms from males caught in July. Nothing, I believe, is known of the embryology of the fish, but Lutken, ${ }^{3}$ in 1880, figured and described the young of two allied forms, Gempylus serpens and Neolotus tripes.

On the same date and at the same place as the preceding, there were taken four specimens of the cow-nosed ray, Rhinoptera bonasus. These were all about of one size, averaging 24 inches wide. A female after being clubbed on the head until insensible, gave birth, while being cut open, to two young measuring $8 \frac{1}{2}$ inches long and $13 \frac{1}{2}$ inches wide. This premature delivery of the young, brought about by muscular contraction due to re-

2Smith, H. M., "The Fishes of North Carolina," N. C. Geological and Economic Survey, Raleigh, 1907.

${ }^{3}$ Lutken, Chr., "Spoila Atlantica," Danske Videnskabernes Selskabs Skrifter, 5te Raekke, Natur. og. Math. Afdèling, Table III., figures 3-8. 
flex action, is by no means unusual, the writer having noticed it on several occasions in both butterfly and sting rays. Not infrequently, however, the young are born while the mother is being killed, the pain causing spasmodic contractions of the muscles of the uterus.

In this connection it is interesting to read in Schomburgk ${ }^{4}$ as follows:

I have frequently observed that the rays, no doubt in consequence of the anguish when secured and transfixed by the poles (harpoons), brought forth their young ones.

A similar occurrence was once noticed by Dr. S. Westray Battle, of Asheville, N. C., who related it to the writer. The young slip very readily out through the genital orifice, and on several occasions (July 29, 1902, for the first time), I have delivered the mother of her young by manipulating her abdomen in the manner familiar to spawn takers. The young are rolled up in tubes, one pectoral fin forming the inner lining of the tube, the other the outer; $i$. e., the fish is rolled up like a sheet of paper beginning at the edge of one pectoral. It is interesting to note that the teeth of these young rays were hard and fit for service, and the spines able to produce a wound.

On May 29 I found on Fort Macon Beach, about one half mile south of the concrete breakwater, a dead and half dried specimen of Raja eglanteria, called "brier ray" because of the curved prickles with which its dorsal region and especially its tail are covered. This is the "clear-nose", of the fishermen, and the dried specimen in question fully justified the appellation, since the membrane joining the rostral cartilages to the pectoral fins was translucent almost to the point of transparency. The fontanelles of the skull, especially the anterior one, were clearly marked out. The total length of this specimen from tip of nose to broken-off end of the tail was 19 inches: the pectorals were rolled up and so hard that it was impracticable to ascertain the width of the fish.

This is the only specimen of the ray which the writer

"Schomburgk, R. H., "Fishes of Guiana," Part II., in Jardine's Naturalist's Library, 1843. 
has seen, and the only one noted in the card catalogue at the laboratory. Of this species, Smith $^{5}$ wrote in 1907:

It has not previously been recorded from North Carolina, although it doubtless occurs along the entire coast of the state. At Cape Lookout, on April 22, 1904, the author observed numerous specimens on the beach and was informed that many are eaught in the deep-water gill nets set in that region.

On June 5 a three-foot male Scoliodon terranove, the ordinary sharp-nosed shark found everywhere in the harbor, was captured at Lawton's Rock. Noticing that he had the tail of an ordinary eel, Anguilla chrisypa, sticking out of his mouth, I opened him and found in his stomach the half-digested remains of two other eels, smaller than the first. This observation leads one to conjecture whether eels constitute a steady article of diet for sharp-nosed sharks.

Lest it should seem strange for the shark to be taken and to die in the boat with this half-eaten fragment of food in his mouth, it may be of interest to add that I have seen in the hold of a menhaden schooner, sharks of the same kind literally full of menhaden, stomach, gullet and mouth; and with menhaden impaled on the teeth half in and half out of the closed mouth. The menhaden fishermen report that this is a very common experience with them.

The spotted sting ray, Aëtobatus narinari, was first described from Brazil by George Marcgrave in his "Historiæ Rerum Naturalium Braziliæ," published in "Historia Naturalis Braziliæ" by William Piso and George Marcgrave at Lugduni Batavorum et Amstelodami, in 1648. In his description of this ray, Marcgrave gives a figure which is perfectly recognizable and indeed is admirable, considering the time when it was drawn.

Yarrow $^{6}$ reports that in his day this ray was very common at Beaufort. But so rare is this fish there at the present time that, in seven summers' fishing, I had never seen one until a female was taken at Rockfish Rock on

${ }^{5}$ Smith, H. M., op. cit.

${ }^{6}$ Yarrow, "Notes on the Natural History of Fort Macon, North Carolina, and Vicinity," No. 3-Fishes, Proc. Acad. Nat. Sci. Philadelphia, Vol. XXIX, 1887. 
June 12, and then I was quite sure that I had found a new species until the director of the laboratory, Mr. Henry D. Aller, positively identified it under the above name. Its width across the utmost reach of the pectorals was 26 inches; length, end of snout to tip of ventrals, 18 inches; length of tail, root to tip, $40 \frac{1}{2}$ inches; tail with two spines, length over all $56 \frac{1}{2}$ inches (tail inserted between bases of ventrals); width between eyes 4 inches.

The most interesting thing about this ray apart from its color is the very unusual structure of its jaws. Whereas, in ordinary rays with pavement teeth, the upper and lower jaws are practically duplicates, in this ray while the upper jaw is of the ordinary shape, the lower is drawn out into a tongue-shaped organ protruding beyond the lips. These would seem to be especially fitted for cracking clams, which dissection proved to constitute its chief food. It should be remarked in passing that the jaws of Aëtobatus are noticeably smaller than the jaws of an ordinary ray of the same size.

On July 3 Mr. Russell J. Coles, of Danville, Va., caught in the bight of Cape Lookout and very kindly brought to the laboratory another ray of this species. This was also a female whose measurements were as fol-

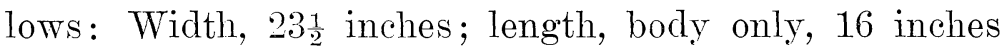
tail, $35 \frac{1}{2}$ inches long and provided with two spines; width between eyes, $3 \frac{1}{2}$ inches. Mr. Coles, notwithstanding his long experience as a fisherman for sharks and rays at Beaufort and Cape Lookout, thought that he too had caught a new species.

As a further evidence of the scarcity of this ray in the Beaufort region, it may be noticed that the card catalogue of the laboratory has records of but two other specimens, In 1901 some fishermen took on the outer or channel side of Shark Shoal, in the deepest part of Beaufort Harbor an Aëtobatus narinari whose dimensions were as follows: Width, 4 feet; length, nose to ventrals, 2 feet and 2 inches; tail, 4 feet and 8 inches long; total length about 6 feet and 6 inches (allow for insertion of tail between ventrals). On August 3, 1909, Mr. C. F. Silvester, of Prinee- 
ton, N. J., took a specimen inside the hook of Cape Lookout. Of this, however, no measurements were made.

Considerable numbers of sting and butterfly rays, Dasyatis say and Pteroplatea machura, were taken at the Narrows. The females of these were commonly found to have gravid uteri. At the beginning of my season's seining, the eggs had on them young in very early stages not longer than 10-12 millimeter's, the "selachian stages" of Alcock. Two eggs were found having what seemed to be membranous egg shells like those found on teleost ova, and one had the ends twisted into chalaza-like structures similar to those in a hen's egg. Alcock seems to have found similar structures in Carcharias melanopterus, a viviparous shark of the Indian Ocean. He writes:

Each young one lay, head forwards, in its own separate compartment of the uterus, in which, further, it was completely enveloped in a very delicate membrane of its own. This delicate envelope is evidently the pseudamnion of Parker, which, according to that author, corresponds with the horny egg-shell of viviparous Elasmobranchs.

Those uteri, which contained embryos having the yolk sac gone or reduced to a mere string, had their whole inner surface crowded with villi, shaggy with them. Both the villi and the deeper layers of the uteri were tremendously vascularized, and the whole uterus in any specimen was greatly distended by this unwonted blood supply. Uteri containing young as above described were filled with and had the young bathed in a milky fluid evidently secreted by the villi (in the absence of a placenta) as nourishment for the embryos until the time of hatching. According to Alcock this "milk" is taken through the open spiracles of the Indian Pteroplatea miciura, a closely allied form, into the mouth, stomach and intestine. Since the Beaufort species likewise have the spiracles wide open, it is fair to suppose that they too feed in the same way. This fluid, somewhat creamy in appearance, was greasy to the touch, and readily coagulated when put into preserving fluids like formalin. I regret that no

${ }^{7}$ Alcock, A. W., "Zoological Gleanings from the Royal Indian Marine Survey Ship Investigator," "Scientific Memoirs by Medical Officers of the Army India,', Part 12,1901.

This' content downiloaded from 181.220.113.075 on February 18, 2018 20:54:10 PM 
particular microscopical examination of this "milk" was made. These observations fully confirm those of Alcock ${ }^{8}$ on Indian Ocean rays in the "Investigator" expeditions. They are necessarily incomplete, but it is the purpose of the writer to make a careful study of the phenomenon of viviparity in sharks and rays.

Lepisosteus osseus, the "shell gar" of the fishermen (so called to distinguish it from the green gar, Tylosurus marinus, formerly Belone longirostris), often comes down from the swamps and upper reaches of Newport River into the brackish water at and even below the Narrows.

In 1908 my fishermen caught several at Cross Rock. Of these, three were thrown on the grated bottom of the gasoline launch, and, with no further attention than having an occasional drenching with a bucket of salt water and being covered from the sun's rays by the corner of an old sail, were brought to the laboratory. Here they were put in a large tank of fresh water, which was aerated only semi-occasionally by a jet from a pet-cock. As a result of this severe experience, one of the fish died. However, the other two survived, though their pectoral and caudal fins were badly split and were congested with blood as a result of their threshing around on the floor of the boat during the journey of more than an hour from the fishing ground to the laboratory. Further, in a short time the fins of the living fish became much worn by contact with the scaling paint of the tank.

These two gars came safely through the winter of 1908-09, thanks to the care given them by the laboratory men under the direction of the superintendent of the station, Mr. Henry D. Aller. On my return to Beaufort on May 26, 1909, I found that the fish had completely regenerated their fins and that these were in as good physical condition as the day, ten months before, when the gars were taken out of the bunt of the seine. However, the larger of the two had the body curved in a curious very flat $S$, which led me to think that it had suffered some injury resulting in deformity. On June 4 this crook had disappeared and the fish seemed to be perfectly

s Alcock, A. W., op. cit.; " A Naturalist on Indian Seas," 1902.

This content downloaded from 181.220.113.075 on February 18, 2018 20:54:10 PM

All use subject to University of Chicago Press Terms and Conditions (http://www.journals.uchicago.edu/t-an 
normal. Later in the day my attention was called by one of the laboratory men to some spawn floating near the bottom of the tank. This was examined and found to have a greenish color, and undoubtedly was the eggs of one of the gars, presumably the larger. The crook in the body of this fish was probably the result of an effort on her part to rid herself of the eggs without the aid of the sexual excitement engendered by the presence and activity of a male as noted by Dean. ${ }^{9}$ The eggs had gone bad-strong evidence that the smaller fish was also a female. When I left Beaufort, at the end of the first week in July, the fish were in prime condition.

Although the water in the tank (size 3 feet by 8 ) in which the fish were confined, was not more than six inches deep and was aerated only semi-occasionally, the fish did not seem to suffer, thanks to their vascularized air bladders. I watched these gars at irregular but fairly frequent intervals during my six weeks' stay, and noticed that the larger fish seldom came to the surface for air, but that one was quite sure in a few minutes' watching to see the smaller do so. Certain preliminary symptoms always preceded this action: the fish would swim around slowly but uneasily, would shake its head from side to side, would raise its snout nearly to the surface of the water and then sink down; finally with almost imperceptible rapidity the snout would be thrust out of the water and the jaws would open and shut with a convulsive snap; then, as the fish slowly sank to the bottom of the tank, the gill covers would expand and one or two large bubbles of air would escape from under each operculum.

The fish were fed simply by putting into the tank live minnows, chiefly Fundulus. These seemed much frightened and would huddle in a corner of the tank as far from the gars as possible. In feeding, a gar would slowly swim behind a Fundulus, make a sudden dash, and seize it crosswise in its long toothed jaw. Then elevating its head, possibly out of water, with a quick jerk the gar would catch the fish head first and speedily swallow it.

${ }^{9}$ Dean, Bashford, "The Early Development of Garpike and Sturgeon,"

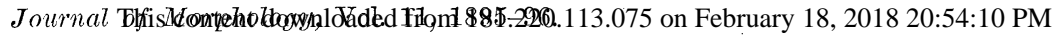

